\title{
WARTIME CHRISTMASES IN FIVE COUNTRIES IN WORLD WAR II
}

\author{
Harry Rose-Innes \\ Groenkloof, Pretoria
}

This article is a first-person account of six wartime Christmases spent in no less than five countries: Kenya, Libya, Italy, Germany and, finally, South Africa. The writer, a gunner with the Second South African Division, was captured at Tobruk and spent the remaining three years of the war, with the exception of short periods of escape, as a prisoner of war.

\section{CHRISTMAS IN KENYA}

Dawn does not "break" in Kenya; it "arrives" in the form of "first light". So it was on Christmas Day 1940 , at our camp at Kabete ten miles outside Nairobi. At 5 am the lush green countryside was suffused with palest light and the morning breeze was gentle. What a day for going to lunch with Mrs Burgess!

The three of us, Howard Bates, Dick Came and myself, all members of the 2nd Section, 2nd AntiAircraft Brigade from Cape Town, had been invited to lunch by Mrs Burgess, who knew Mrs Bridgman from Cape Town, because of an association in the White Highlands of Kenya - going back many years - who, in turn, was my Aunt.

I was the only one who knew how to get there.
Everything hinged on "the Ngong road". On this fabulous Christmas Day I felt like being adventurous, so I announced that I was going to walk there across country. "But do you know which way to go?" asked the others. "Yes", I replied, with misguided assurance, "that way", pointing. "You chaps take the transport vehicle into town, and then ask a taxi to take you along the Ngong road as far as Mrs Burgess' house - about number 1130".

By 10 am I was all spruced up and ready to go. Dressed in my khaki bush jacket and shorts, wearing khaki gaiters, brown boots and pith helmet, I stood on the edge of a donga, looking down into brush eight feet high, an obstacle that had to be crossed. With my heart in my mouth I slithered down into what had to be an ideal haven for cobras, puff adders and mambas. In five staggering strides I was across and scrabbling frantically at

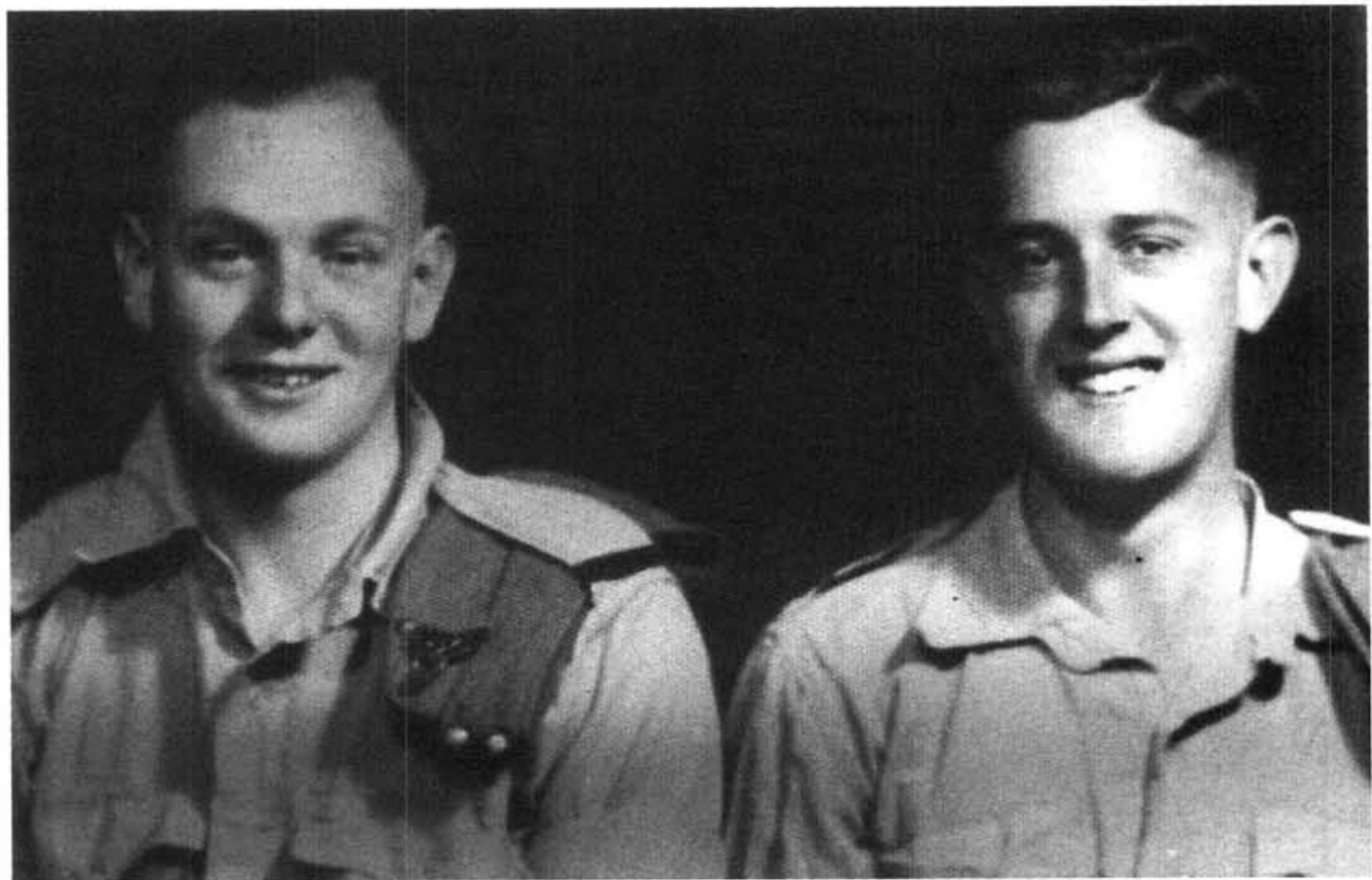

Howard Bates and Harry Rose-Innes (right) - "the inseparable lance-bombadiers", 1940. 
the steep red earth bank on the opposite side. Finally I stood panting for breath, sweating profusely, and gazing across a flat grass-land plain.

When I had dusted myself off and recovered my composure I walked in the general direction in which I had pointed. In a little while I came upon a wellworn track, heading in the right direction. Walking at a good pace I covered about two miles before looking at my watch. It was now eleven o'clock and the sun was more than uncomfortably hot. Not knowing how much further I had to walk, I decided to increase my pace - by marching! Drill parade stuff, you understand.

I had done about a mile when a local Kikuyu tribesman appeared from nowhere, and walked parallel to me. "Ngong road?", I asked hopefully. he pointed forward, and speeded up his pace. I tried hard to keep up but could not. Somehow I had to slow him down, as I tried one of the only four Swahili words I had learned so far. "Pace, pace!" I ordered, meaning "slowly, slowly" (as I thought). He looked at me strangely and then, with real determination, fairly flew over the veld!

Running to keep up I commanded again; "Pace, pace, man!" Just then we came to a fork in the track, and he went left. With a gasp of relief I went right! It was now $12.30 \mathrm{pm}$ and lunch was at $1 \mathrm{pm}$.

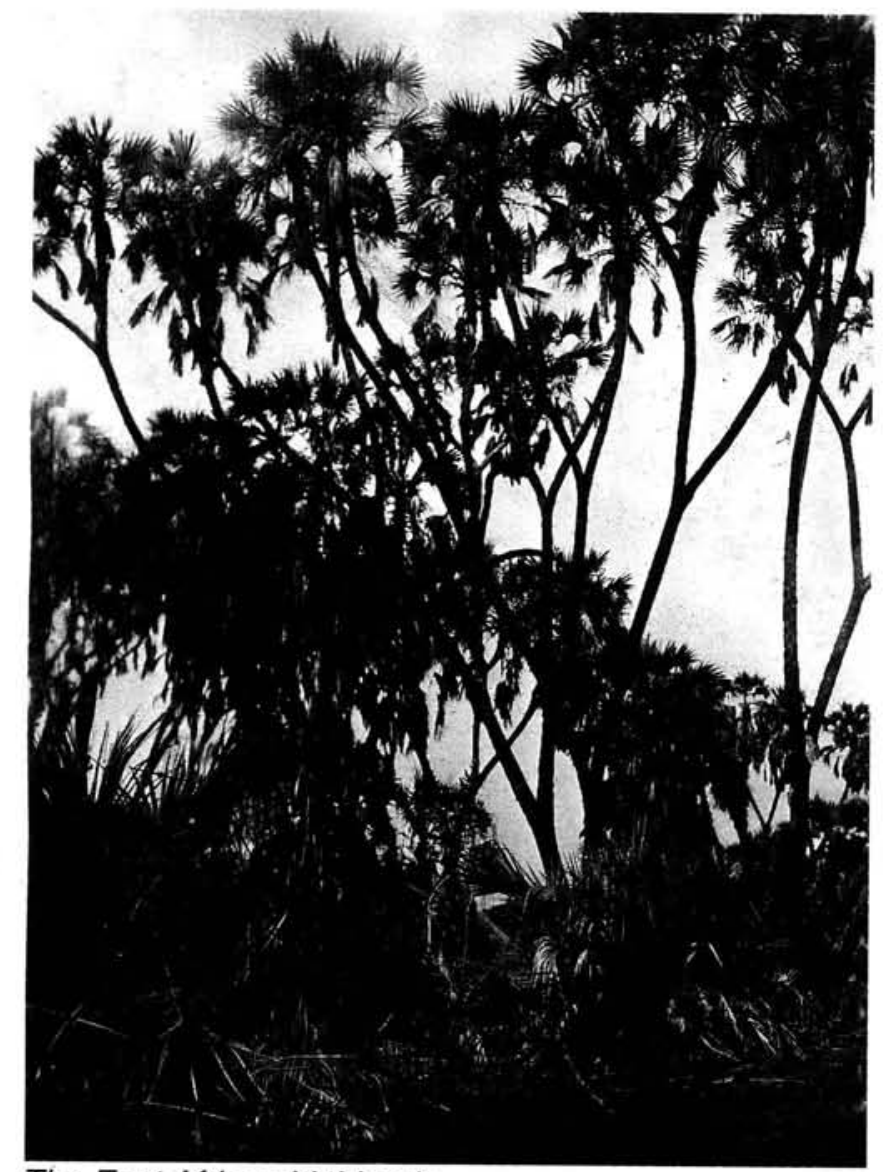

The East African highlands.
Seeing a line of trees ahead I made for them, and bisected the Ngong road! No houses in sight, and no street numbers. As I stood in indecision a dilapidated Austin rolled to a halt.

"Want a lift?" asked a pretty young woman. "Mrs Burgess' house", I gasped. "Hop in! You're nearly there!"

At $1.15 \mathrm{pm}$ I opened the little white gate and approached an open front door. Taking one look at me Mrs Burgess exclaimed; "Where on earth have you been?" "Come inside at once, and have an iced beer!"

Mr Burgess asked anxiously: "I hope you didn't come through the Reserve. "I suppose I did!", I answered. He shook his head in disbelief. "Noone does that", he muttered. He explained that "pace, pace" meant "faster, faster", which explained everything!

Howard and Dick grinned at me. "You should try the iced paw-paw", they chorused.

The lunch was straight from heaven. Iced melon, roast duck, green peas, roast potato, yellow rice. And lemon pudding; and Christmas pudding - carried round the table by Aaron, clade in white and wearing a red fez! The pudding seemingly on fire, from the lighted brandy sauce.

The kindness and loving care we experienced then are with us still. Because, you see, Howard Bates, Dick Came, and I are all alive after 55 years, and are still great friends and in touch with each other.

\section{CHRISTMAS AT CAPUZZO, LIBYA, 1941}

I had chosen the pre-dawn, 2-6, guard duty, and stood "stoksielalleen in die middel van die nag" while our gun crew slept in the wadi below. A snatch of the Desert Song wafted through my mind; "One alone, to be my own ..." "How unsuitable!", I thought. This section of this God-forsaken land that was Libya was as unlike the desert as anything imaginable. Boulder-strewn shale and solid rock surrounded us. For the first time, ever, we had been unable to dig a gunpit, and had to build one out of sandbags. Only yesterday I had disturbed an Egyptian horned viper and, in picking up a stone with which to kill it, had found another underneath! The phrase "jet propelled" had not yet been invented, but it applied to me as I leapt backwards.

I shivered, as much from the memory, as 


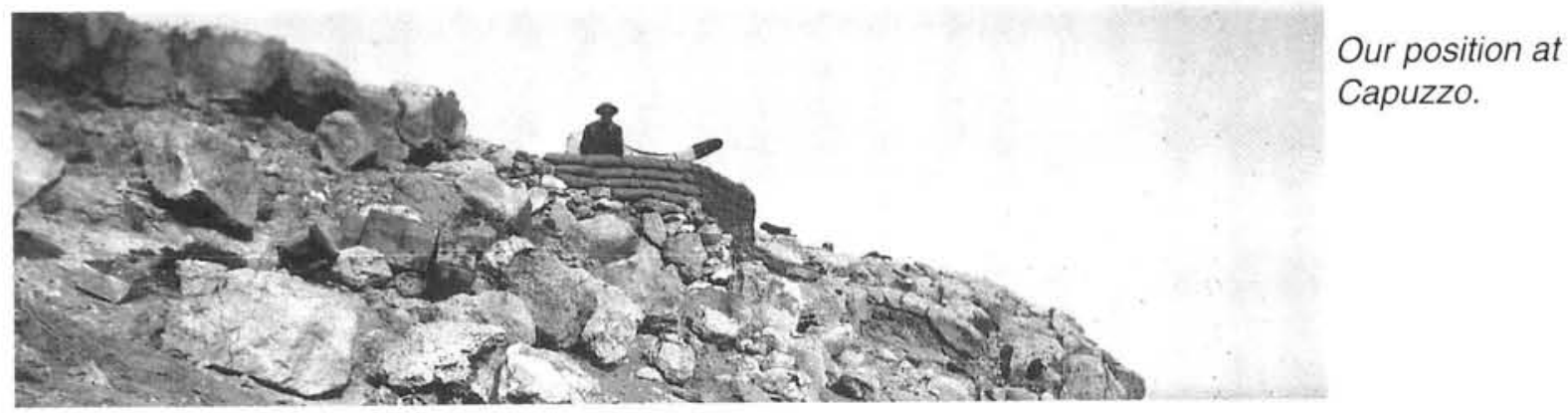

Gun crew at Capuzzo:

"Mac", Ginger and

Wally. Note our tent in the wadi below.

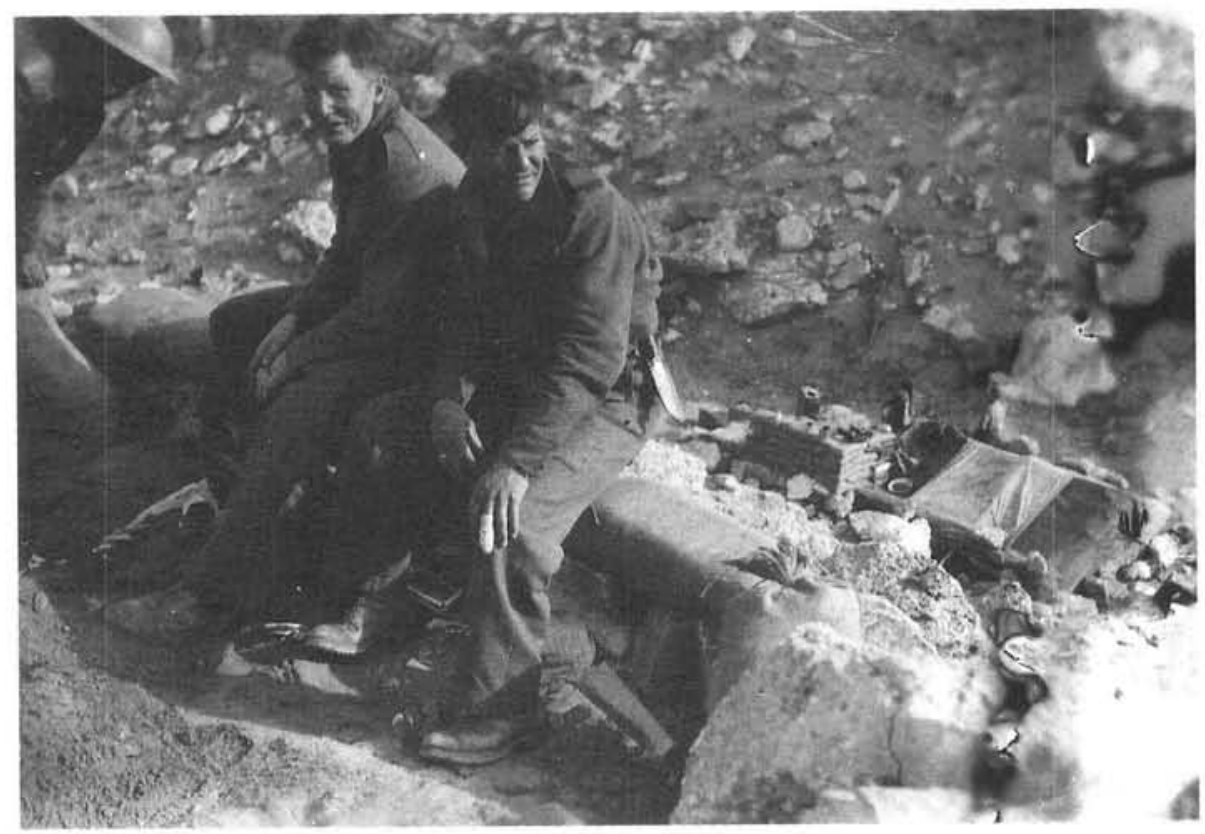

from the biting cold that penetrated my greatcoat and made me pull my balaclava down under my chin. My feet were freezing.

From my vantage point I looked down on the gun crew. All South Africans, but of Scots, Welsh, English, Dutch, French and German descent. We had come a long way from Nairobi; and we knew each other pretty well. The Section had lost only two men so far; one taken by a crocodile in the Juba river, the other badly burnt by a fire in the back of a three-tonner.

It was time for me to start the morning "brew" - the life-giving tea that would warm us up - and to rouse my friends by shouting "Happy Christmas, julle donners!"

It was warmer in the shelter of the wadi and the chaps turned out willingly, "Let's have $\mathrm{M}$ and $\mathrm{V}$ (meat and vegetables)" suggested Gordon Wilson - our cook for the day, and Mayor of Simon's Town 30 years later! We agreed.

"I am still cold", complained MacLean, "do you think we could have a tot of brandy for a toast?" "Why not?" I answered, "It's Christmas Day". The normally quiet Wally Jones said; "I propose a toast to all those far away".
"All those far away", we echoed, each occupied with his own thoughts, his own mental pictures, and his own misty eyes.

"Let us assume that there will be no planes today", I suggested. "So you stay with the gun, Dup, while we go and look over the edge".

It was a hundred metres to "the edge" and, as we arrived there and looked down on the Mediterranean, 2000 feet below, the sun broke through the cloud cover and seemed to cast a searchlight onto a tiny white craft about half a mile out to sea. It looked like a child's toy.

We were still trying to decide what it was when there was a little puff of smoke, followed by a swirling, swishing, rushing noise. Then we saw, high in the sky above us, a shell streaking through the atmosphere - with a parabola such as would be made by a howitzer gun shell. Then I realised what it was. "That's the Monitor EREBUS", I said. "it is a floating platform, on which is mounted a fifteen inch gun, like those used by battleships!"

Filled with awe we watched for half an hour, during which time at least six more shots were fired. Everytime the gun fire, we cheered! It was firing at Bardia, to be attacked soon by the 2nd S.A. Division. 


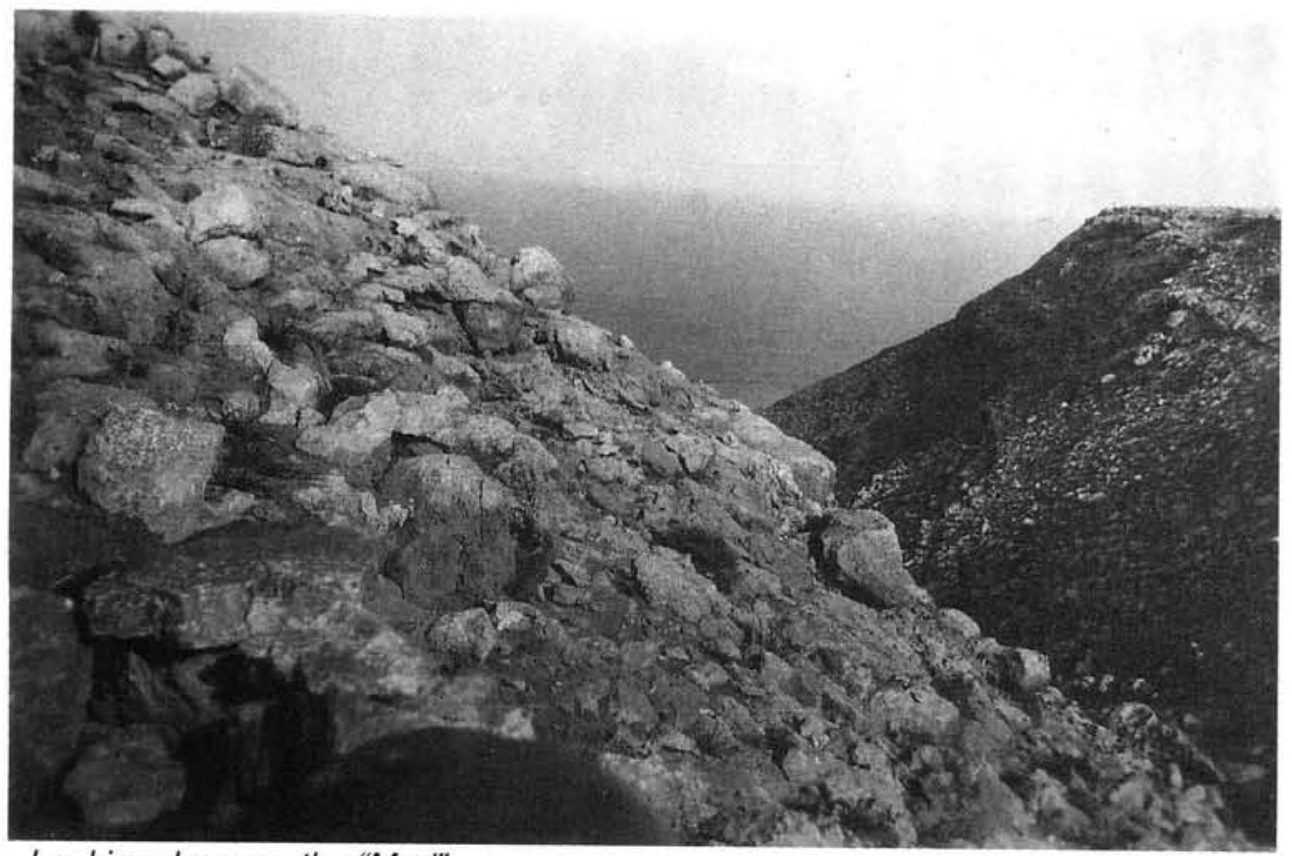

Looking down on the "Med".

What a Christmas Day celebration!

We wondered whether anyone else had ever seen a shell in flight. Just as we had wondered about the "miracle" we had seen a few months earlier, from a point not many miles away. On the escarpment above Sollum we saw, in the shimmering heat of mid-morning, the entire town of Sollum "suspended in mid-air", through light refraction. The mirage, including caves and mud huts, had been reflected upwards 1500 feet!

\section{CHRISTMAS AT LUCCA HOSPITAL, ITALY, 1942}

The military hospital in the ancient town of Lucca, near Florence, was known officially as "Campo 202". Staffed by Italian nuns, it was controlled by an Italian military doctor, but operated by 13 hardworking British and Dominion doctors, assisted by about a hundred orderlies from South Africa, New Zealand, Australia and Great Britain.

The prisoners of war fortunate enough to be contained in this haven of peace and rest had been captured at Sidi Rezegh, Gazala, Tobruk, and the Mareth line. The wounded had in most cases been transferred from field-dressing stations to hospital ships, and thence by train to Lucca. The sick had drifted in from prison camps all over Italy; the rigours and hardships of camp life had re- sulted in hundreds of cases of dysentery, malaria, jaundice and frostbite.

Sister Letitia stood only 4 feet 2 inches but she controlled Ward 5 with a rod of iron. She had only to stand at the end of the Ward, with ladle at the ready, and say quietly: "Silencia!" and she got it. Even my great friend Dennis de Villiers, strapping sheep farmer from Beaufort West, and the only other Second Section gunner in the hospital, quailed beneath her imperious gaze! In her ward of 60 men she had Ram Singh, champion chess player, left leg amputated above the knee; Jock, choir

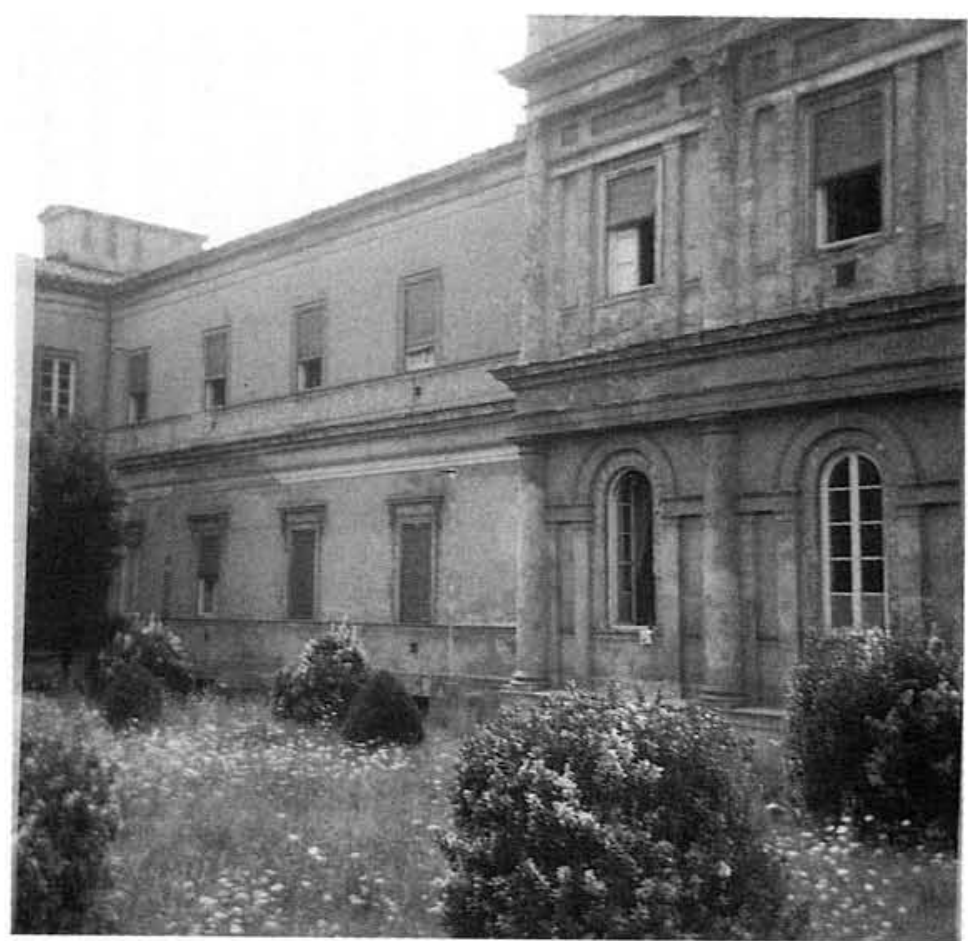

The hospital at Lucca. 


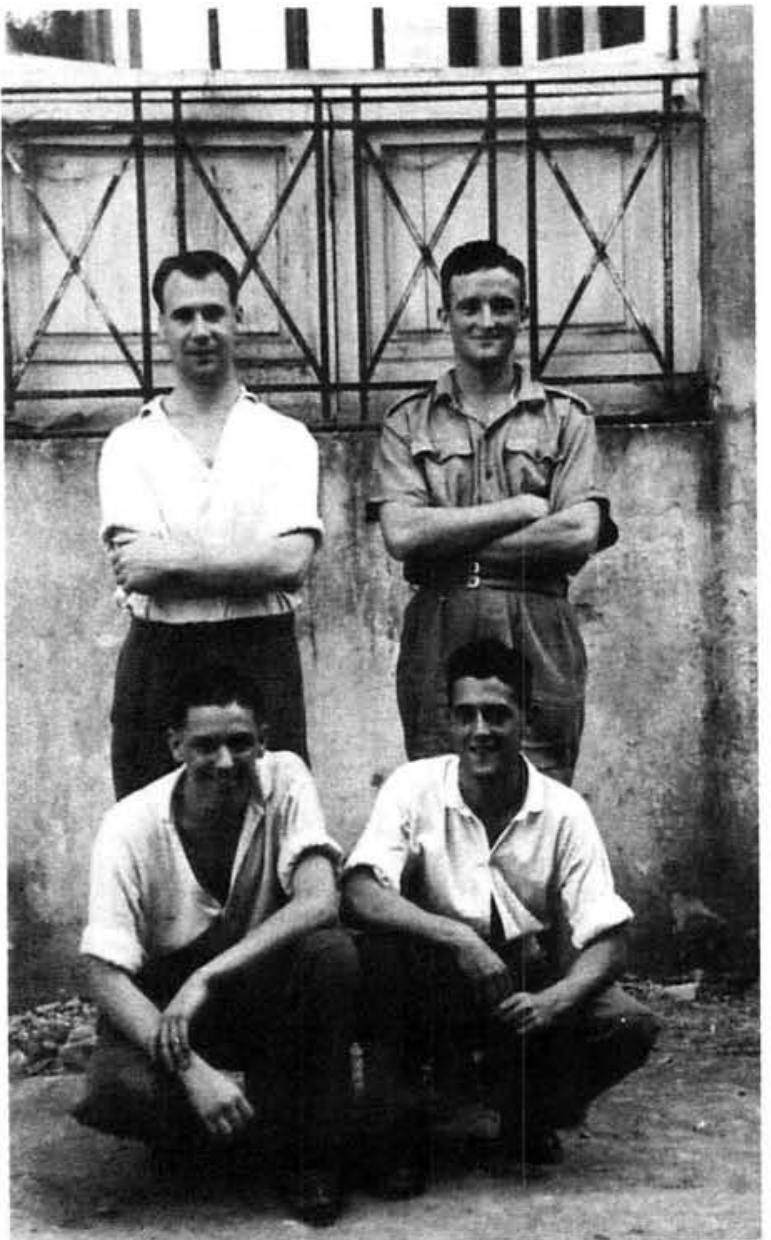

Four Allied POWs at Lucca Hospital:

Harry Rose-Innes is front right.

tenor, dragging his useless right leg; Jimmy, jazz tenor, his right sleeve empty and pinned neatly to his jacket; Green, conscientious objector still - even though he had lost his right foot; Captain Yates, leading light in dramatics, limping badly, with a smile upon his lips; "Sailor", a British Naval rating, whose lower jaw had been smashed and who now had to walk about holding a kidney-dish under his face. Some of the hospital's six hundred ...

It was Christmas Eve, and we had just finished our bowls of "rice broth". This was water in which macaroni had been boiled. After the macaroni had been removed, boiled rice was added to the water and the water and rice was served hot. We never saw the macaroni!

There were no books, magazines, or newspapers; only a few chess sets; and bed patients found time hanging heavily, unless they were too ill, or injured, to care.

"Buono Notte!" Sister Letitia called out, as she switched off the ward lights. One blue shaded light only remained on. Men stirred restlessly as they made themselves comfortable and prepared to sleep.
I was just drifting from awareness of those around me into my own private world, when I heard a voice say, softly, "One ... two ..." Then unbelievably, came the softly sung words of the immortal song; "Silent Night, Holy Night".

Gradually the voices of the voluntary choir increased in strength, until their Christmas message could be heard the length of the Ward, and men, everywhere, twisted to listen. The little group sang with shoulders back and heads held high; they sang clearly, with humility and reverence. They represented Britain and every combatant Dominion whose men were held prisoner in the hospital. Sergeant "Chuck" Chapman, Royal Canadian Tank Corps; Capt. Gordon Hooker, British ward doctor; Capt. Geoffrey Haines, R.A.M.C., doctor and volunteer dentist; Lieut. Claude Studleigh (ex R.S.M. of a British regiment); Cpl "Jimmy" James, Royal Signal Corps; major Thompson, R.A.M.C., eye specialist and Officer Commanding, Lucca Hospital; Private Reg Leverton, S.A.M.C.; Capt. Webster, New Zealand surgeon; Private "Ted" Broomhead, Australian Medical Corps, and Methodist minister extraordinary (whose book Barbed Wire in the Sunset was published in Adelaide in 1944, after his repatriation).

Their voices died away and for an instant there was utter silence. Then, softly, came the stirring ...

"Once in Royal David's City stood a lowly cattle shed ..."

followed by: "Last night I lay asleeping, I had a dream so fair, I stood in old Jerusalem, beneath a temple there ..."

When, eventually, the last notes died away, the Minstrels had achieved their aim. They had created an air of courage and hope, which prevailed long after their footsteps had receded, and their choroused "Merry Christmas to you all", and Ted's, "God Bless you, Boys", had echoed in their wake.

We slept a dreamless sleep and it seemed no time at all before Sister Letitia's cheery "Buono Natale" and her shy "Merry Christmas" was heard.

Then she rapped on the steel urn with her ladle and said loudly; "Milk rice!" So? What was new? We had it every morning! She laughed gaily and called "Andiamo" (let's go!) for she had brought us a Christmas present ... Rice with sugar, as usual, but with REAL MILK.

This little "Angel of the Church" had not only handsewn collars on to the shirts of 150 men, in her off-duty hours (2-4 am) but she had now achieved her own private miracle, and brought us joy. 


\section{CHRISTMAS AT MOOSBERG, MUNICH, GERMANY, 1943}

Our cattle truck was moving smoothly enough and the seventy men inside it were less restless. We had been standing for twenty-four hours, except when it was our turn to sit down for fifteen minutes, and now we seemed to be travelling up a gradient.

"The Brenner Pass, between Italy and Switzerland", I reasoned. The thought brought a wry smile to my face. I remembered that, when I was hanging by my hands from the window of a speeding hospital train - and running out of strength, I had thought; "I can't very well hang here until we reach the Brenner Pass!" And now here I was, under quiet different circumstances.

At about 6 am we rolled quietly into Innsbruck station, to find the platform covered in snow. After half an hour there was a jolt as a new engine was coupled to our "train", and we moved off. To where, we did not know.

We arrived at Stalag VIIA, at Moosberg outside Munich, in mid-afternoon. It was the transit camp through which all POW's from Italy were processed: those who had been brought straight from camps all over Italy, and those who had escaped and had been recaptured - such as myself.

No time was wasted and we were speedily herded into the ablution block, to shower and be deloused, while our clothing was deloused in a special chamber.

It was during this process that I made a friend, a New Zealander, who had worked as a stoker on the N.Z. Railways. I, a "Springbok" (or SouthAf) and he, a "Kiwi" (or Joker) were drawn to each other by Commonwealth ties - which in those days really meant something. And it was Steve who gave me a Christmas present of inestimable value.

When we had finished showering in heavenly hot water, we stood around "drying off", because we had no towels, and waiting for our clothes to be returned.

At that time I no longer had my British battle-dress, which had been swopped for civilian clothes in the mountains, which had finally been replaced by others when I was recaptured for the second time. I

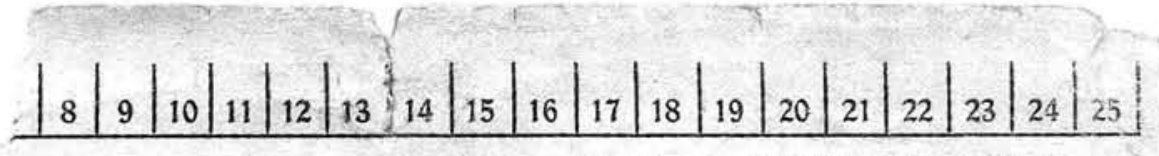

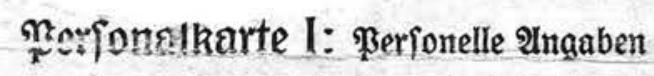

Siriegsgefangenen=Stammlager: MUHLBERG ON ELBE

Rame: ROSE-INNES

Bornamit: HARRY WILLAM

Staatångebörigfeit: S. $A F P / C A$.

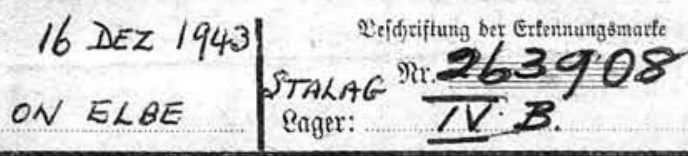

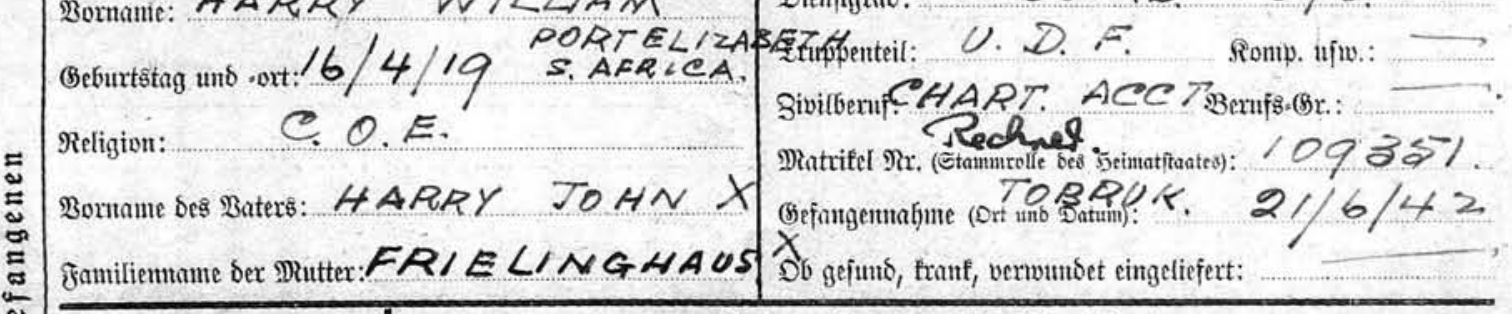

BOMB U/O.

(atidatio

\begin{tabular}{|c|c|}
\hline $\operatorname{Brobje}$ & Sharfarbe \\
\hline
\end{tabular}

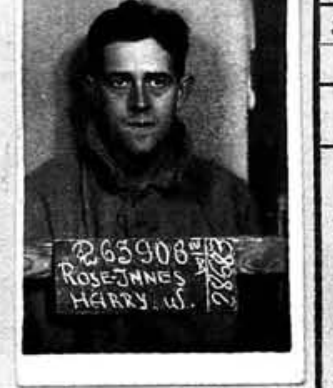

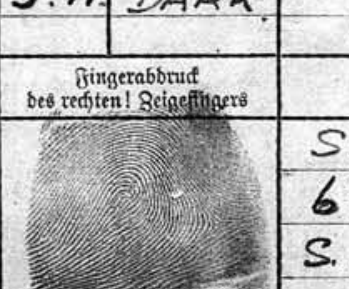

- 
now wore a light blue Polish half-coat, Russian green pants, and yellow Dutch clogs filled with straw; no vest, no underpants and no socks!

When we emerged into the cold night air, the cold was intense and I hobbled because of the condition of my feet, covered in chillblains and swollen. Steve walked by my side.

We halted outside a barrack with closed door. When the door was opened we saw that the barrack was completely empty - except for a small table 3 feet by 2 feet.

"The table, Steve", I exclaimed. Without hesitation he burst away from our squad and reached the table in a dead heat with a British soldier! "This table is bespoke, mate", Steve announced. "Like hell it is!" Eeveryone else was busy finding "a place" against the walls, or dossing down where they stood, and the table stood out like a little island. When I finally arrived I said: "I only need the space beneath, Steve; he can have the top!" Looking sideways at Steve's massive shoulders and brawny forearms, the soldier concurred!

Unbelievably, the 3 feet $x 2$ feet space was enough for me to curl up in and protect my feet. Whenever I have seen such a table over the past 50 years, I have coveted it!

The following day, Christmas Day, it was snowing heavily. At all costs I had to keep my circulation going, so, after a mug of ersatz coffee and two slices of ersatz bread, I left the barrack and tried to walk somewhere. All the barracks were sealed against the driving snow, and no-one was about.

I rounded the corner of a shed and came upon a German sentry, armed with rifle and fixed bayonet. I stopped to examine this phenomenon. The sentry signalled to me to move on.

The devil was in me and, without thinking, I asked, in Afrikaans, "Waarom?" The sentry was incensed. "Waarum?" he exploded, meaning "How dare you question my orders?" At the same time he took two quick steps forward and lunged at me with his bayonet!

I stood my ground, thinking, "he can't leave his post. Let him dance and prance a bit!" Besides, in getup, he did not even know who or what, I was.

Then I hobbled back to my hut, and the security and friendship of my own kind. The photograph printed with this story was actually taken at Stalag IVB, Mühlberg-on-Elbe, a month later, but it well illustrates my apparel and my mood on Christmas Day 1943 - when I was at my lowest ebb ever.

\section{CHRISTMAS AT MÜHLBERG- ON-ELBE, GERMANY, 1944}

Stalag IVB was almost paralysed by the cold on the day before Christmas 1944. It was the coldest time we had ever known. Very little rain and snow, just iron hard frost; fences and trees coated white. Icicles hanging from the eaves; ice on window panes, inside and out: condensation on the roof, dripping down on to the tables.

The icy wind that lunged at the barracks in vicious blasts had its origin in the Russian Steppes, where the snow lay thick upon the ground and the bodies of soldiers - German and Russian - did too. There was no heat within the barrack in which I stood, and I hunched my shoulders within my greatcoat and stamped my frozen feet.

Unexpectedly the quiet voice of McLaren (Mac) Wiley from Graaff-Reinet spoke at my ear. "'Pop' Benson died yesterday", he said. "The funeral is this afternoon. Will you please come?"

"Not Pop", I thought. The whole camp had been wanting him to make it. At 64 his upright, sprightly step had been the pride of all us youngsters. "I'll come", I answered, "when is it?" At 3 pm it was snowing gently, and the wind had abated slightly. "Mac" gathered his small group together, and we tagged on to the detachment of German soldiers detailed as a firing party. The firing squad stood rigidly to attention as they pointed their rifles skywards, then fired on command. It would be wrong to say that the echoes died away - they were blown away.

We held a midnight Anglican Communion service at $11.30 \mathrm{pm}$, that Christmas Eve, and were in bed by midnight. In bed? I suppose so! There had been another call by the Hut Leader for "one bedboard per man" and each man had now only six. Two for his head and shoulders, one for his hip, one for his knees, and two for his feet. The straw-filled mattress protruded through the gaps, creating a corrugated effect.

However, we would have fuel for the communal coal stove on Christmas Day; if we included the coal brickettes that the coal squad would make out of coal dust during the night with their frozen hands! We owed them a great debt.

I covered my body with my one thin blanket, and spread my overcoat on top, being careful not to cover my feet. These were already blue, purple and, in places, black with cold, and I had found that, if I kept them uncovered I could sleep. If they warmed up, I could not stand the red-hot needles that resulted. On a really bad day the German 
guards would have to come to my bunk to check me for rollcall!

In the early hours of Christmas morning a rustling noise was heard at the far end of the barrack. Gradually it increased in intensity until I could catch phrases: "Two trucks at the station!" "American parcels!" Our British Red Cross parcels had run out two weeks ago, and we had been existing on German rations only. Milit, Swedes, pea soup; ersatz bread and ersatz coffee; and spuds. The rumour that was now spreading throughout the camp turned out to mean that there would be one American food parcel between 5 men, and bulk food issue (rice and flour, etc) to the Camp Cookhouse - all supplied by the American Red Cross.

The parcels were found to contain tinned Christmas pudding, custard, coffee, and tinned sausages, powered egg, and oats. All luxuries that we had not tasted for years. What a surprise. What a feast. What a Christmas!! And ... wait for it ... 50 cigarettes per man ... "Thank you, American Red Cross", we whispered as we attended the Methodist Church Service at $11 \mathrm{am}$, in the Theatre normally used for stage plays; "and thank you, O Lord, for your gracious mercy and everlasting help".

Later in the afternoon I went to see the play "Dover Road", put on by the Dramatic Society. The Englishman who played the lead part, would be playing as hooker for England in their rugby match against South Africa the following day. (South Africa won.) Sergeant "Fiks" van der Merwe, of the 2nd S.A. Police Brigade, played eighth man - as he did for the Springbok team in 1949. South African Donnie Wilson, who played soccer, helped the English team beat Scotland on the same afternoon. The English volleyball team, which included two Guardsmen of 6 feet 9 inches, was beaten by the
Poles, half their size it seemed, who behaved like India rubber balls!

So many memories, of so long ago.

\section{CHRISTMAS IN THE EASTERN CAPE, SOUTH AFRICA, 1945}

When I left England on 3 September 1945, and sailed for South Africa as an ex-P.O.W. being repatriated on the spanking new WILLEM RUYS (to be renamed many years later ACHILLE LAURO, and to be sunk) I never dreamed that I would be spending Christmas in the mountains at Hogsback. But so it was.

The air at Hogsback is something special; something to be experienced in tranquillity, and to be savoured. This is especially so on the little plateau above the guest house, "Arminel", and the more commercial "Hydro", in the valley. The tongue of land ends abruptly at one point, and one is able to look down upon the town of Alice on the plain below. When Alice is unbearably hot, the faintest cool breezes embrace the plateau, and the small collection of houses above the plain.

In pre-war days Mr Summerton lived there. His first wife, English born, had died and, after many years of loneliness, he had married the Black woman who looked after him. He treated her with the greatest respect, but kept her in the background. They had a son, who drove a lorry and carried on a business as a haulage contractor. That was in 1935.

Now, in 1945, nothing had changed, except that Mr Summerton had died. And, of course, that many Black academics had passed through Fort Hare University and were heading for a future which, in

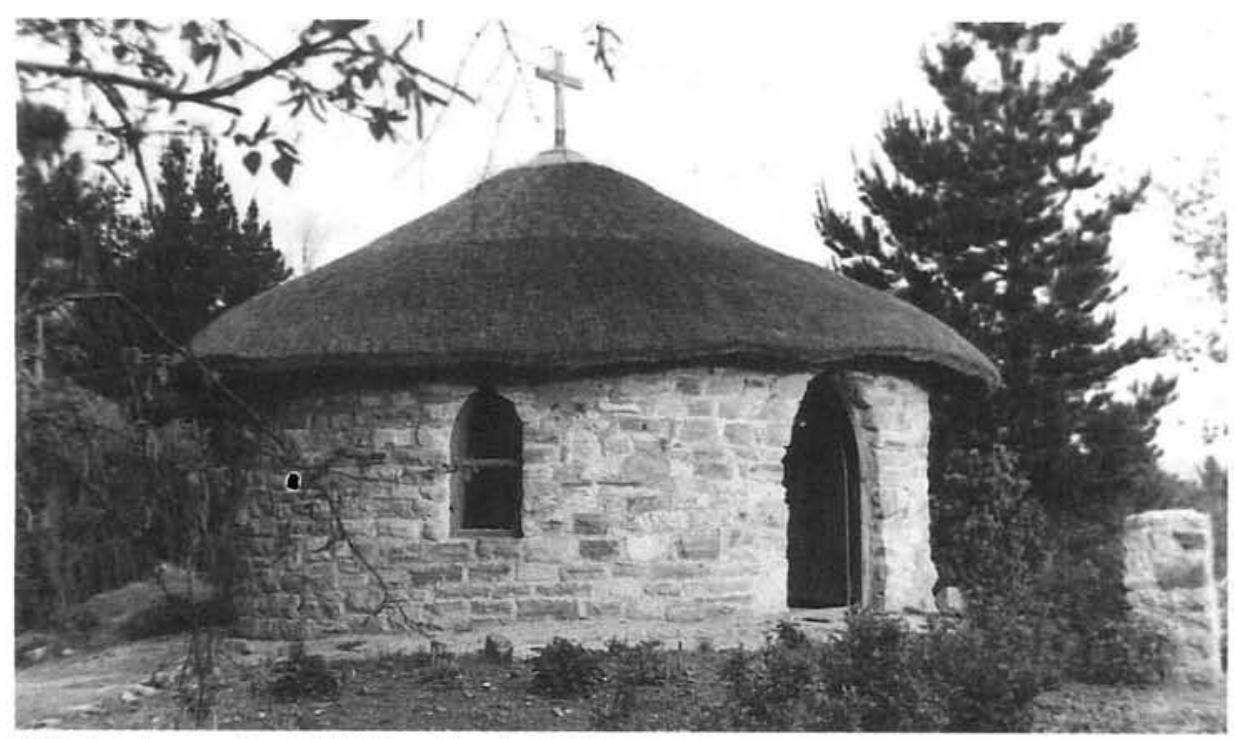

St Patricks-on-the-Hill, Hogsback, 1945. 


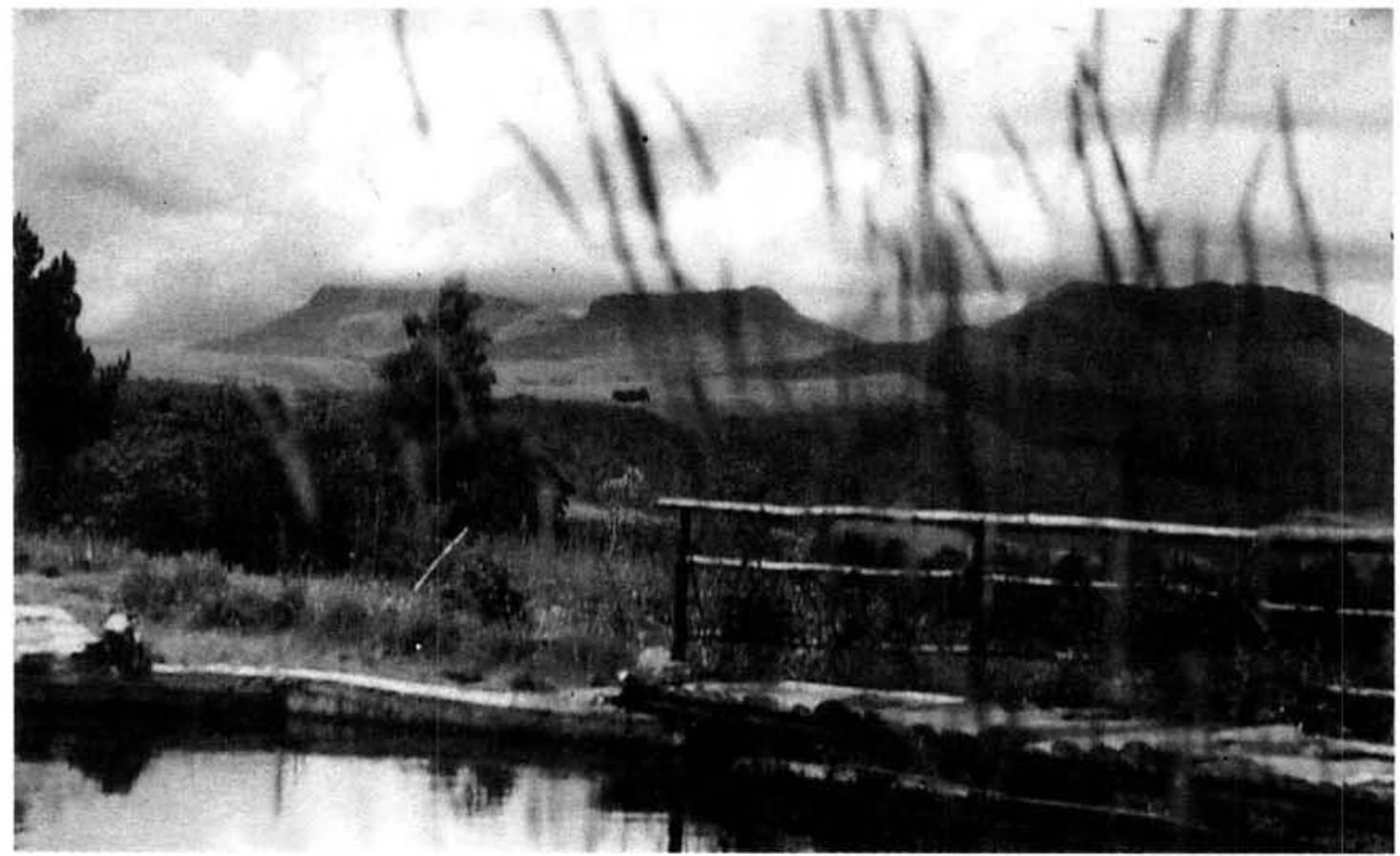

The Hogsback, 1945.

1990, would open untold treasures and fields to Black and Coloured people. But that lay in the future.

On Christmas Day, 1945, the air was unusually still at Hogsback. The Christmas bees sang their song of delirious delight; the butterflies seemed enormous as they flitted from bloom to bloom; and the world was at peace, after six years of war.

The little round rondavel of beautifully crafted, matching stone, that was "St Patrick's on the Hill", a private Church erected by Professor Hobart Horton of Rhodes University - himself a P.O.W. in Italy and Germany - was our gathering point that Christmas morning.

The Church had room for only twelve people, and there were about twenty people. Some would have to stand outside. I chose to be one of these.

As I looked out over the mountains surrounding us - including the distant Hogsback range itself, whose name was used by the community in which we stood - I saw South Africa, the land of my birth, the land for which I had fought, and had been imprisoned as a captured soldier. And I knew that there was not another like it; for I had seen for myself.

It was a pearl that had to be cared for; to be developed for the good of all its inhabitants.
The Church service had begun and it was time for the first hymn. There was no organ, or piano, as there had been none in the camps in Italy and Germany in which we had been held captive. So a lead-voice had to be forthcoming. It was. Yes, it is as I found it to be in the camps. Amongst every 100 men there are only two leaders. These leaders have the solid support of two reliable back-up men. There are also four supporters ready to be "involved". The remaining 92 men are "followers", who have to be shepherded, guided, encouraged, and pleaded with. This, in short, is LIFE. And no amount of education, training, benefits and privileges will change that.

"O, God! Our help in ages past ..." The words rang in my ears, and emphasised what I had learnt as a P.O.W. With the help of Our Lord anything is possible. Without his help, nothing durable can be achieved!

So, as I close the book on my memories of World War II, of 50 to 55 years ago, I say:

"Let us cease being indulgent. Let us require discipline from those around us and demand that those who co-inhabit this land give at the very least, their very best. No two men are alike but each has something to offer: something to justify his/her personal existence. Thus is it meant to be". 